\title{
The Degradation of Starch by Strains of Group A Streptococci having Related Antigens
}

\author{
BY NUALA CROWLEY \\ Bacteriology Department, Royal Free Hospital, London
}

\begin{abstract}
SUMMARY : Strains of Group A streptococci produced an extracellular carbohydrase which degraded starch. The enzyme in crude undialysed culture filtrates bore a general resemblance to pancreatic diastase. Amylolytic activity was decreased in environmental conditions which also affected streptococcal proteinase, namely in cultures grown at $23^{\circ}$, in filtered broth, or after serial mouse passage. Amylase production was associated with hyaluronidase production in strains having the type-specific $M$ antigen 4, or the non-specific $T$ antigen 4, whereas proteinase-positive strains of the same group of closely related specific Types $4,24,26,28,29,46$ were usually amylase-negative; but the association between production of any two of the three enzymes was not complete. Hyaluronidase-positive Type 22 strains did not produce amylase, and with two exceptions, a Type 2 strain and a strain serologically unidentified, other representative serological types were amylase-negative, though some strains degraded starch in growing cultures.
\end{abstract}

The use of starch in fermentation studies of streptococci was suggested by Andrewes (1930) and by Sherman (1937), and used by Keogh \& Simmons (1940), who compared endemic Australian strains with Griffith types, and found that starch was fermented by strains serologically classified as Types 1, 2, 4, 9, 10 and 28. Maxted (personal communication), using starch plates, found that ability to split starch, though commonly shown by Type 4 strains, was infrequent in other endemic British strains examined at the Streptococcal Reference Laboratory. While studying strains isolated during a survey of hyaluronidase production Crowley (1944) observed that ability to split starch was displayed by Type 4 strains ( $T$ antigen, non-specific) with the greatest hyaluronidase activity. Both polysaccharidase activities were absent, however, in Type 4 strains which were strongly proteinase positive. In this connexion Dr S. D. Elliott (personal communication) observed that proteinase added to cultures suppressed hyaluronidase activity, and suggested that intermittent proteinase production might explain variable behaviour by hyaluronidasepositive strains. The experiments described in this paper were made to establish the incidence of amylolytic activity in relation to the antigenic components, to investigate the coincidence of different polysaccharidases elaborated by the same strains and to study the effect of proteinase on the carbohydrase activity of the strains, with reference to the occasional anomalous behaviour of streptococcal hyaluronidase which has been reported.

\section{MATERIAL AND METHODS}

Source of the strains. Hyaluronidase-producing strains were isolated during 1941-3 in a survey of hyaluronidase activity in endemic group A streptococci and subsequently preserved in the dried state. The Types were identified by slide 
agglutination and classified at that time as Type 22, or Type 4 (some showing cross-agglutination with Type 24 serum). These results were confirmed with type-agglutinating sera prepared in the Streptococcal Reference Laboratory. Representative Group A strains, serologically identified by precipitation of the type specific $M$ antigen, were supplied by $\mathrm{Dr}$ V. D. Allison, Streptococcal Reference Laboratory, Colindale. Recently-isolated starch-positive strains were received from the same source. A proteinase-positive strain ' $K 48$ ', used as a control, was supplied by Dr S. D. Elliott, and a hyaluronidase-positive strain, now known as 'McA4', derived from the original Griffith Type 4 strain deposited in the National Collection of Type Cultures, was supplied by Dr Douglas McClean in 1941.

Cultures. Glucose beef infusion broth was made by the method of Todd \& Hewitt (1932) and modified by varying the brand of peptone, buffer and method of sterilization. Five batches of beef were used, but the media compared in any one experiment were prepared from broth infused from a single batch. Proteose peptone (DIFCO), Neopeptone (DIFCO) or Evans's peptone (Evans Medical Supplies, London) were used. Sodium $\beta$-glycerophosphate $(2.5 \%, w / v)$ was substituted for bicarbonate buffer (Todd \& Hewitt, 1932). The broth was sterilized by autoclaving for $10 \mathrm{~min}$. at $10 \mathrm{lb}$. pressure, or twice Seitz-filtered through E.K. pads. Soft agar was made by mixing one volume of specified broth with one volume of nutrient digest agar (McCartney, Park Hospital Laboratory, Lewisham). Nutrient agar plates, used freshly poured for the study of colonial morphology, were enriched with $2 \cdot 0 \%(\mathrm{w} / \mathrm{v})$ proteose peptone, $0.2 \%(w / v)$ glucose and $10-15 \%(v / v)$ horse serum.

Concentration of culture filtrates. Cultures were grown for 2 days in 0.5 or 11. volumes of broth. Greater yields of enzyme per vol. medium were produced by growing strains for 2 days at $37^{\circ}$ in soft agar, which was frozen at $-10^{\circ}$ for 2 or more days, and the liquid then extracted by thawing. This method, originated by Heimer (personal communication) to increase the yield of staphylococcal phage, was successfully adapted by Maxted (1948) for the extraction of streptococcal 'grouping enzyme'. After centrifugation the supernatant was sterilized by filtration and refrozen. Partial concentration was obtained by slow thaw fractionation, and collection of samples of approximately the same specific gravity; protein values were estimated by the copper sulphate method of Phillips, Van Slyke, Dole, Emerson, Hamilton \& Archibald (1945). The filtrates were further concentrated by precipitation with 1.5 vol. acetone after chilling at $-10^{\circ}$. The supernatant was removed and the precipitate

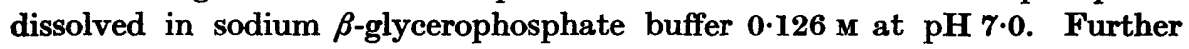
concentration was obtained by repeated precipitation with acetone, or with 2.5 vol. ethanol.

Typing of streptococci. Type-specific $M$ antigens were identified by the method of Swift, Wilson \& Lancefield (1943) and $T$ antigens by slide agglutination (Griffith, 1984) in duplicate cultures grown at $37^{\circ}$ and $22^{\circ}$ (Elliott, 1943).

Proteinase. The clotting time of milk-thiolacetate was estimated by the method of Elliott \& Dole (1947), substituting boiled skimmed milk for milk powder. The destruction of $M$ antigen was estimated by specific precipitation tests. 
Hyaluronidase. Mucin clot prevention was tested by the method of McClean (1942), using umbilical hyaluronate or synovial fluid as substrate.

Viable counts were made by the method of Miles \& Misra (1938).

Capsular material was demonstrated by the indian ink method of Butt, Bonynge \& Joyce (1936).

Hydrolysis of starch. Two-fold dilutions of culture supernatants or filtrates were made in sodium $\beta$-glycerophosphate buffer (pH 7.0). Samples $(0.5 \mathrm{ml}$.) were mixed with $1 \mathrm{ml}$. watery starch solution $(0 \cdot 2 \% \mathrm{w} / \mathrm{v}$, soluble starch, Analar) and incubated in a water bath at $37^{\circ}$. After 2, 4, $6 \mathrm{hr}$. and overnight incubation a colour reading was recorded using $1 \%$ Lugol's iodine, added drop by drop from a pipette until the colour was maintained in incompletely hydrolysed mixtures. This method necessitated the use of four tubes for each dilution and was' sometimes modified when the relative activities of strains became apparent. To minimize the personal error involved in reading a rapidly changing range of colours only grosser differences were recorded by the following scheme: ++++ , colourless supernatant, slight flocculant deposit, colourless after standing; +++ , colourless supernatant, flocculant deposit, red remaining in deposit; ++ , mauve to pink supernatant, purple flocculant deposit; + , colourless supernatant, blue flocculant deposit; \pm , coloured supernatant, blue flocculant deposit; $a+$ or \pm at 2,4 or $6 \mathrm{hr}$. that remained unchanged after further incubation was designated $\beta$-amylase type activity, but further progress to the erythro-dextrins, achroö-dextrins and final disappearance of coarse floccules was designated $\alpha$-amylase type activity and could usually be distinguished in low dilutions after $4 \mathrm{hr}$. Concentrated filtrates hydrolysed starch very rapidly and it was necessary to take readings at $10 \mathrm{~min}$. intervals.

\section{EXPERIMENTAL}

\section{Hydrolysis of starch}

Broth cultures. The results of iodine tests on overnight cultures (Neopeptone autoclaved broth) containing $0.5 \%$ starch showed no correlation with results previously obtained with the same strains using starch plates. The $\mathrm{pH}$ value of overnight cultures in starch broth was found to be $5 \cdot 0-6 \cdot 0$, the hyaluronidase production of positive strains was decreased sometimes ten-fold, and some proteinase-negative strains became positive. Supernatants of broth cultures without starch were then tested in two-fold serial dilutions against $0.2 \%$ starch as substrate. The incidence of strains which split starch in these conditions is seen in Table 1. All strains positive on plates had some degree of activity in solution, but the plate test gave no indication of relative activity.

Culture supernatants. The substrate containing $0 \cdot 2 \%$ starch was selected after testing six strongly positive strains in a wide range of dilutions with varying concentrations of Analar starch. After $18 \mathrm{hr}$. at $37^{\circ}$ it was found that all strains in dilutions $1 / 2$ to $1 / 100$ hydrolysed starch $(++++$ reading) in concentrations below $0.25 \%$, but $0.3 \%$ and higher concentrations were not completely hydrolysed by the lowest dilutions. The different starch concentrations were obtained by diluting strong solutions (weighed out with $0.5 \mathrm{~g}$. 
differences) so that every concentration was duplicated once, and the middle and lower concentrations triplicated. The end-point was clear-cut and easy to read.

Table 1. Degradation of starch by representative strains of endemic Group $A$ streptococci

$M=$ type-specific representatives, $M$ antigen identified by precipitin tests. $\mathbf{T}=$ nonspecific representatives, $T$ antigens identified by slide agglutination (growth at $37^{\circ}$ and $23^{\circ}$ ). Classification of serological types is based on that of Lancefield \& Dole (1946).

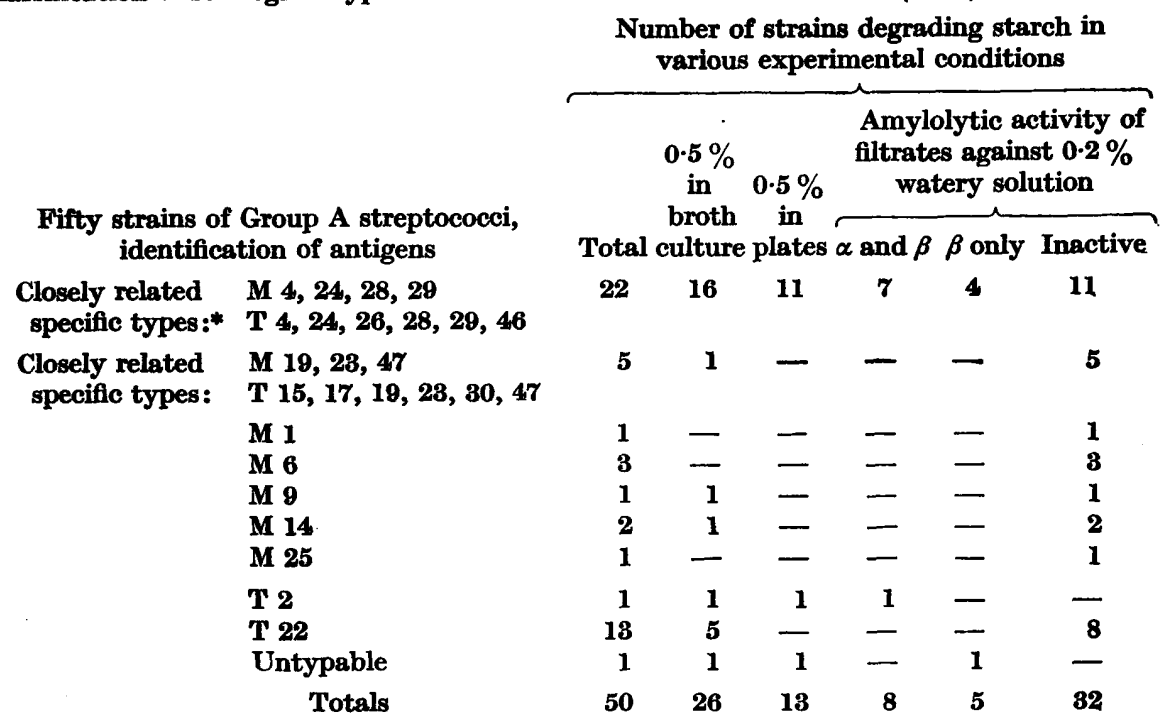

* The antigenic analysis of these strains is shown in Table 11.

The appearance of coarse floccules in homogeneous solutions was the first naked-eye indication of change when the iodine test was still positive ("starch blue'). With larger volumes of enzyme + substrate mixtures, solutions showing even slight flocculation could be filtered rapidly, although the homogeneous solutions did not pass a No. 50 Whatman filter paper. This loss of viscosity was the first change detected in mixtures, and many strains which did not show any other activity were able to depolymerize starch solutions. Strains showed diversity both in rate and degree of attack, two types of activity analogous to those of $\alpha$ - and $\beta$-amylase being distinguished. This was investigated with cell-free filtrates.

\section{Activity of cell-free filtrates}

Table 2 demonstrates the production of an extracellular carbohydrase by a Type 4 streptococcus. The activity of this filtrate was dextrinogenic, like that of $\alpha$-amylase, and was increased by partial concentration of protein in the fraction. Some activity was lost after precipitation with acetone, which appeared to affect $\alpha$-amylase activity, but had no effect on $\beta$-amylase activity or the ability to decrease the viscosity of $0.2 \%$ starch solution by qualitative test. The filtrate was also hyaluronidase-positive but proteinase-negative. 
Table 2. The amylolytic activity of a cell-free filtrate

Iodine test: $++++=$ colourless; $+++=$ trace of erythro-dextrins; $++=$ erythrodextrins in deposit/red; $\pm 1+=$ erythro-dextrins in supernatant, unchanged starch in deposit.

\begin{tabular}{|c|c|c|c|c|c|c|}
\hline \multicolumn{2}{|c|}{ Strain 'H713' } & \multicolumn{5}{|c|}{$\begin{array}{l}\text { Hydrolysis of } 0.2 \% \text { aqueous starch solution. } \\
\text { Time in water bath at } 37^{\circ}(\mathrm{hr} .)\end{array}$} \\
\hline $\begin{array}{l}37^{\circ} ; \mathbf{2} \text { days } \\
\text { Neopepton }\end{array}$ & $\begin{array}{l}\text { incubation. } \\
\text { autoclaved }\end{array}$ & $\mathbf{1}$ & 2 & 4 & 6 & $16+$ \\
\hline $\begin{array}{l}\text { Before } \\
\text { concentration }\end{array}$ & $\begin{array}{l}\text { Supernatant, } \\
1000 \mathrm{ml} . \\
\text { Culture } \\
\text { filtrate }\end{array}$ & - & $\begin{array}{c}++ \\
\text { floccules } \\
++ \\
\text { floccules }\end{array}$ & $\begin{array}{l}+++t \\
++t+\end{array}$ & $\begin{array}{l}++++ \\
++++\end{array}$ & $\begin{array}{l}+++t \\
++t+\end{array}$ \\
\hline $\begin{array}{l}\text { Fractionated by } \\
\text { freexing and } \\
\text { thawing }\end{array}$ & $\begin{array}{l}\text { Concentrated } \\
\text { to } 200 \mathrm{ml} \text {. } \\
\text { Boiled for } \\
80 \mathrm{~min} \text {. } \\
\text { Heated at } 57^{\circ} \\
\text { for } 1.5 \mathrm{hr} \text {. }\end{array}$ & $\begin{array}{c}++++ \\
(30 \text { min.) } \\
- \\
-\end{array}$ & $\begin{array}{c}++ \\
- \\
-\end{array}$ & $\begin{array}{c}+++ \\
- \\
-\end{array}$ & $\begin{array}{c}++t \\
- \\
-\end{array}$ & $\begin{array}{c}+t+ \\
- \\
-\end{array}$ \\
\hline Strong fraction & $\begin{array}{l}\text { Redissolved } \\
\text { acetone } \\
\text { precipitates }\end{array}$ & $\begin{array}{l}+++ \\
(45 \text { min. })\end{array}$ & $+t+t$ & $++t+$ & $+++t$ & $+t+t$ \\
\hline $\begin{array}{l}\text { Weak fraction } \\
\text { (discarded) }\end{array}$ & $\begin{array}{l}\text { Redissolved } \\
\text { acetone } \\
\text { precipitates }\end{array}$ & - & \pm & \pm & \pm & + \\
\hline
\end{tabular}

Relative activity of comparable filtrates. Crude filtrates derived from four strains grown in soft agar are compared in Table 3. In soft agar cultures some strains previously negative became proteinase positive irrespective of the brand of peptone in the medium. Of the four filtrates in Table 3, three contained active proteinase, clotting milk-thiolacetate mixture within $10 \mathrm{~min}$. The strain 4226 remained proteinase-negative, and $\mathrm{H713}$ was the only strain producing hyaluronidase. Strains $R 1823$ and 1182 were strongly positive on starch plates.

Substrate specificity. Substrates of maize and potato starch (Thomas Kerfoot and Sons, Ltd., Vale of Bardsley, Lancs.) and potato starch (British Drug Houses Ltd.) were degraded by filtrates. Maize starch solutions, believed to contain a greater proportion of amylopectin, were separated into two fractions, a homogeneous supernatant giving a true amylose blue iodine reaction, and a flocculant deposit giving a blue-brown colour. Filtrates previously classed as $\beta$-amylase-positive failed to attack the amylase fraction, but destroyed the flocculant fraction, and $\alpha$-amylase-positive filtrates attacked both fractions. All filtrates degraded glycogen, but streptococcal Group A polysaccharide was not attacked by homologous or heterologous filtrates.

\section{Factors influencing the activity of cell-free filtrates.}

The optimal conditions for activity were studied using several Type 4 filtrates in comparison with other types. Using comparable $\alpha$-amylase-positive filtrates Type 4 strains showed almost identical behaviour; therefore only one strain is usually shown in the tables.

The effect of temperatures of $37^{\circ}$ and $50^{\circ}$ is shown in Table 4, with two concentrations of the substrate, and the effect of the hydrogen-ion concentration at five $\mathbf{p H}$ values in Table 5. 
The effect of salt concentration. The effect of $\mathrm{NaCl}$ concentration was tested only on undialysed crude culture filtrates. $\mathrm{NaCl}$ concentrations greater than $1 \%(w / v)$ decreased the rate of hydrolysis in distilled water and in buffer

Table 3. Comparison of the amylolytic activity of four strains in partly concentrated crude filtrates of equivalent specific gravity and protein value

Concentrates made by fluid extraction from frozen soft agar cultures $250 \mathrm{ml}$. Evans's peptone autoclaved broth $+250 \mathrm{ml}$. nutrient agar (digest, McCartney). Iodine test for degree of starch hydrolysis: $++++=$ colourless; $+++=$ trace of erythro-dextrins in deposit/pink; $++=$ erythro-dextrins in deposit/red; $+=$ erythro-dextrins in supernatant and deposit/purple.

Final dilutions of enzyme sample in buffer $\mathrm{pH} 7 \cdot 0$

\begin{tabular}{|c|c|c|c|c|c|c|}
\hline \multirow{2}{*}{$\begin{array}{l}\text { Starch hydrolysis } \\
\text { strains }\end{array}$} & \multirow{2}{*}{$\begin{array}{l}\text { Time in } 37^{\circ} \\
\text { water bath } \\
\text { (min.) }\end{array}$} & $\mathbf{1} / \mathbf{2}$ & $1 / 4$ & $1 / 8$ & 1/12 & \multirow[t]{2}{*}{$1 / 16$} \\
\hline & & \multicolumn{4}{|c|}{ Degree of starch hydrolysis } & \\
\hline H713 Type 4 & $\begin{array}{l}15 \\
30 \\
45 \\
60\end{array}$ & $\begin{array}{c}+++ \\
+++ \\
++++ \\
++++\end{array}$ & $\begin{array}{c}\overline{++} \\
++++ \\
++++\end{array}$ & $\begin{array}{c}- \\
++ \\
++ \\
+++\end{array}$ & $\begin{array}{c}- \\
++ \\
++ \\
+++\end{array}$ & $\begin{array}{c}\bar{z} \\
++ \\
+++\end{array}$ \\
\hline 4226 Type 2 & $\begin{array}{l}15 \\
30 \\
45 \\
60\end{array}$ & $\begin{array}{l}+++t \\
+++t \\
+++t \\
+++t\end{array}$ & $\begin{array}{l}++++ \\
++++ \\
++++ \\
++++\end{array}$ & $\begin{array}{c}+++ \\
+++ \\
++++ \\
++++\end{array}$ & $\begin{array}{c}- \\
++ \\
++ \\
+++t\end{array}$ & $\begin{array}{c}- \\
++ \\
++ \\
+++\end{array}$ \\
\hline R 1823 Type 24 & $\begin{array}{l}15 \\
30 \\
45 \\
60\end{array}$ & $\overline{-}$ & E & $\begin{array}{l}- \\
- \\
-\end{array}$ & $\begin{array}{l}- \\
- \\
-\end{array}$ & $=$ \\
\hline 1182 Untypable & $\begin{array}{l}15 \\
80 \\
45 \\
60\end{array}$ & $\frac{-}{+}$ & 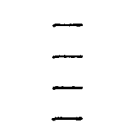 & $\bar{z}$ & $\begin{array}{l}\bar{z} \\
\bar{z}\end{array}$ & $=$ \\
\hline
\end{tabular}

Table 4. The effect of temperature on the amylolytic activity of crude filtrates, using two concentrations of substrate, at $\mathrm{pH} 7 \cdot 0$

Iodine test results for starch hydrolysis recorded as in Tables 2 and 8.

\begin{tabular}{|c|c|c|c|c|c|c|c|c|}
\hline \multirow{2}{*}{$\begin{array}{l}\text { Culture } \\
\text { filtrates } \\
\text { of strains }\end{array}$} & \multirow{2}{*}{$\begin{array}{c}\text { Water } \\
\text { bath } \\
\text { tempera- } \\
\text { tures }\end{array}$} & \multirow{2}{*}{$\begin{array}{c}\text { Starch } \\
\text { in sub- } \\
\text { strate } \\
(\%)\end{array}$} & \multicolumn{6}{|c|}{ Starch hydrolysis after various times (min.) } \\
\hline & & & 10 & 20 & 30 & 40 & 50 & 60 \\
\hline $\mathbf{H 7 1 3}$ & $\begin{array}{l}\mathbf{8 7 7 ^ { \circ }} \\
50^{\circ}\end{array}$ & $\begin{array}{l}\mathbf{0 \cdot 2} \\
\mathbf{0 \cdot 5} \\
\mathbf{0 \cdot 2} \\
\mathbf{0 \cdot 5}\end{array}$ & $\begin{array}{l}++ \\
= \\
-\end{array}$ & $\begin{array}{c}++ \\
+ \\
-\end{array}$ & $\begin{array}{c}++t \\
+t \\
-\end{array}$ & $\begin{array}{c}+++ \\
+++ \\
-\end{array}$ & $\begin{array}{c}+++ \\
+++ \\
-\end{array}$ & $\begin{array}{c}+++ \\
+++ \\
=\end{array}$ \\
\hline $\mathbf{4 2 2 6}$ & $\begin{array}{l}37^{\circ} \\
50^{\circ}\end{array}$ & $\begin{array}{l}0.2 \\
0.5 \\
0.2 \\
0.5\end{array}$ & $\begin{array}{l}++ \\
++ \\
+ \\
\pm\end{array}$ & $\begin{array}{c}+++ \\
+++ \\
+ \\
\pm\end{array}$ & $\begin{array}{c}++++ \\
++++ \\
+ \\
\pm\end{array}$ & $\begin{array}{c}++++ \\
++++ \\
+ \\
\pm\end{array}$ & $\begin{array}{c}++++ \\
++++ \\
+ \\
\pm\end{array}$ & $\begin{array}{c}++++ \\
++++ \\
+ \\
\pm\end{array}$ \\
\hline
\end{tabular}

(pH 7.0). Hydrolysis was most rapid in distilled water when the $\mathrm{NaCl}$ concentrations were less than $0.1 \%$, but in buffer the greatest activity was found in two ranges of $\mathrm{NaCl}$ concentration, namely $0.6-0.9 \%$ and $0.1-0.05 \%$. These results suggested that a high sodium-ion concentration was inhibitory, 
but no conclusions have been drawn about the effect of chloride-ion concentration (Table 6).

The effect of enzyme inhibitors. McClean (1942) reported inhibition of hyaluronidase by heparin, and monoiodoacetic acid inactivates proteinase (Elliott, 1945). Sodium thiolacetate and $\mathrm{NaCl}$ were included as controls in the experiment shown in Table $\%$.

Table 5. The effect of different hydrogen-ion concentrations on amylolytic activity

Hydrolysis of $0.2 \%$ starch solution after $80 \mathrm{~min}$. at $37^{\circ}$ at various $\mathrm{pH}$ values. Degree of hydrolysis measured by iodine test and recorded as in Table 4.

\begin{tabular}{|c|c|c|c|c|c|}
\hline & \multicolumn{5}{|c|}{ pH values } \\
\hline & $4 \cdot 6$ & $5 \cdot 8$ & $7 \cdot 0$ & $7 \cdot 4$ & $\mathbf{8 \cdot 2}$ \\
\hline Culture filtrates & \multicolumn{5}{|c|}{ Degree of starch hydrolysis } \\
\hline $\begin{array}{l}\text { Hr18 Type 4 } \\
\text { 4226 Type } 2 \\
\text { R1828 Type } 24 \\
1182 \text { Untypable }\end{array}$ & $\begin{array}{l}+ \\
+ \\
-\end{array}$ & $\begin{array}{l}+ \\
+ \\
\pm \\
-\end{array}$ & $\begin{array}{c}++++ \\
++++ \\
\pm 1+ \\
\pm\end{array}$ & $\begin{array}{l}++ \\
+ \\
+ \\
\pm\end{array}$ & $\begin{array}{l}++ \\
+ \\
+ \\
\pm\end{array}$ \\
\hline
\end{tabular}

Table 6. The influence of $\mathrm{Na}^{+}$concentration on the amylolytic activity of comparable crude filtrates

Iodine test for degree of starch hydrolysis as in previous tables. Starch solution $(0.2 \%, w / v)$ in phosphate buffer ( $\mathrm{pH} 7 \cdot 0)$ containing $\mathrm{NaCl}$ as shown (\%). Hydrolysis after 1 hr. at $87^{\circ}$.

\begin{tabular}{|c|c|c|c|c|c|c|}
\hline & & \multicolumn{4}{|c|}{$\mathrm{NaCl}(\%)$} & \multirow{2}{*}{$\begin{array}{l}\text { In water } \\
\text { at pH } 6 \cdot 8\end{array}$} \\
\hline & & $2 \cdot 0-1 \cdot 0$ & $0 \cdot 9-0 \cdot 6$ & $0 \cdot 5-0 \cdot 05$ & $0 \cdot 04-0 \cdot 01$ & \\
\hline & & \multicolumn{5}{|c|}{ Degree of starch hydrolysis } \\
\hline $\begin{array}{l}\text { Crude filtrates } \\
\text { undialysed }\end{array}$ & $\begin{array}{l}\text { H713 Type 4 } \\
\text { McA4 Type } 4 \\
4226 \text { Type } 2 \\
1182 \text { Untypable }\end{array}$ & $\begin{array}{l} \pm \\
+ \\
+ \\
\pm\end{array}$ & $\begin{array}{l}++++ \\
++++ \\
++ \\
\pm\end{array}$ & $\begin{array}{c}+++ \\
++ \\
++++ \\
\pm\end{array}$ & $\begin{array}{c}++++ \\
+++t \\
++ \\
\pm\end{array}$ & $\begin{array}{c}++++ \\
++++ \\
++++ \\
\pm\end{array}$ \\
\hline
\end{tabular}

It is not clear whether the inhibitory effects of heparin and monoiodoacetic acid indicate differences in the strength of the filtrates, or a fundamental difference between the strains. In higher concentrations heparin inactivated both filtrates, but monoiodoacetic acid $(0 \cdot 1 \mathrm{M})$ did not completely inactivate the filtrate 4226. The retarding effect of sodium thiolacetate on one filtrate may have been due to a change of hydrogen-ion concentration ( $\mathrm{pH}$ value $5 \cdot 0-5 \cdot 4)$ which occurred after incubation for a few minutes at $37^{\circ}$.

\section{Factors influencing production of streptococcal amylase}

For convenience the extracellular carbohydrase activity which has been demonstrated is now referred to in terms of the substrate, but there is no evidence of absolute substrate specificity. 
Cultural conditions. Strains were grown for carbohydrase production in Neopeptone autoclaved broth with phosphate buffer, $\mathrm{pH} 7 \cdot 4-7 \cdot 6(\operatorname{Rogers}, 1944)$, and in proteose peptone autoclaved broth (bicarbonate buffer, $\mathrm{pH} \mathrm{7.8)} \mathrm{for}$ proteinase production, but to study the effect of proteinase it was desirable to produce all the enzymes in the same medium. Bicarbonate buffer did not maintain a $\mathrm{pH}$ above $\mathbf{7 \cdot 0}$ for so long a period as sodium $\beta$-glycerophosphate, therefore the first modification was a change of buffer while retaining proteose

Table 7. The influence of heparin, monoiodoacetic acid and sodium thiolacetate on the activity of streptococcal amylase, at $\mathrm{pH} 7 \cdot 0$

Degree of hydrolysis of starch measured by iodine test recorded as in Table 4.

\begin{tabular}{|c|c|c|c|c|c|c|}
\hline \multirow{3}{*}{$\begin{array}{l}\text { Culture } \\
\text { filtrates } \\
\text { from strains }\end{array}$} & \multirow{3}{*}{$\begin{array}{l}\text { Hydrolysis time } \\
37^{\circ} \text { water bath } \\
\text { (min.) }\end{array}$} & \multicolumn{5}{|c|}{$\begin{array}{l}\text { Substrate starch solution }(0.2 \%) \text { in phosphate buffer } \\
\text { with addition of }\end{array}$} \\
\hline & & Nil & $\underset{0.5 \%(w / v)}{\mathrm{NaCl}}$ & $\begin{array}{c}\text { Sodium } \\
\text { thiolacetate } \\
0.01 \mathrm{M}\end{array}$ & $\begin{array}{c}\text { Monoiodo- } \\
\text { acetic acid } \\
0 \cdot 001 \mathrm{M}\end{array}$ & $\begin{array}{c}\text { Heparin* } \\
0.01 \% \\
(\mathbf{w} / \mathbf{v})\end{array}$ \\
\hline & & \multicolumn{5}{|c|}{ Degree of starch hydrolysis } \\
\hline H713 & $\begin{array}{l}20 \\
40 \\
60\end{array}$ & $\begin{array}{l}+++t \\
++++ \\
+++t\end{array}$ & $\begin{array}{c}+t \\
++t \\
+t+\end{array}$ & $\begin{array}{l}++++ \\
++++ \\
+++t\end{array}$ & - & - \\
\hline 4226 & $\begin{array}{l}20 \\
40 \\
60\end{array}$ & $\begin{array}{l}++t+ \\
+++t \\
+t+t\end{array}$ & $\begin{array}{l}++t+ \\
++t+ \\
++t+\end{array}$ & $\begin{array}{l}++ \\
++ \\
++\end{array}$ & $\begin{array}{l}++t \\
+++ \\
+++\end{array}$ & $\begin{array}{l}+ \\
+ \\
+\end{array}$ \\
\hline
\end{tabular}

* Heparin: $10 \mathrm{ml}$. of 5000 unit solution in $40 \mathrm{ml}$. of buffer (Evans Sons, Lescher \& Webb, Runcorn; 100,000 units = approx. 1 g.).

peptone. In an attempt to increase growth, on the assumption that this would also increase enzyme production, the broth was sterilized by filtration. In spite of profuse growth, the production of all the enzymes was diminished. The influence of cultural conditions on production was then investigated with reference to peptones and method of sterilization. The results obtained with four modifications of the same basal broth are shown in Table 8 .

The number of viable organisms was greatest in proteose peptone broths. Proteinase was not found in any culture. Hyaluronidase (strain H713) was found in Neopeptone autoclaved broth in high titre, in proteose peptone autoclaved broth in lower titre, but was much decreased in both filtered broths.

The effect of incubation at $23^{\circ}$. Elliott (1943) found that incubation at $22^{\circ}$ ' unmasked' $T$ antigens of Group A streptococci which could not be detected at $\mathbf{3 7}^{\circ}$, and that proteinase production was also suppressed at $\mathbf{2 2}^{\circ}$ (Elliott, 1945). In the previous experiment it was found that the same cultural conditions affected all three enzymes; the experiment was repeated incubating cultures at $23^{\circ}$. Rapidly growing cultures $\left(37^{\circ}\right)$ were inoculated into $100 \mathrm{ml}$. of broth in bottles which were incubated at $23^{\circ}$ for 5-7 days. Samples were removed daily and kept frozen at $-10^{\circ}$ until the sets were complete; all tests were then made together using the same batches of substrate. (The same procedure was 
followed in the $37^{\circ}$ series.) The results are shown in Table 9. After 1.5 days' incubation the number of viable organisms was greater in $23^{\circ}$ cultures.

Table 8. The effect of brand of peptone and method of sterilization on the production of amylase

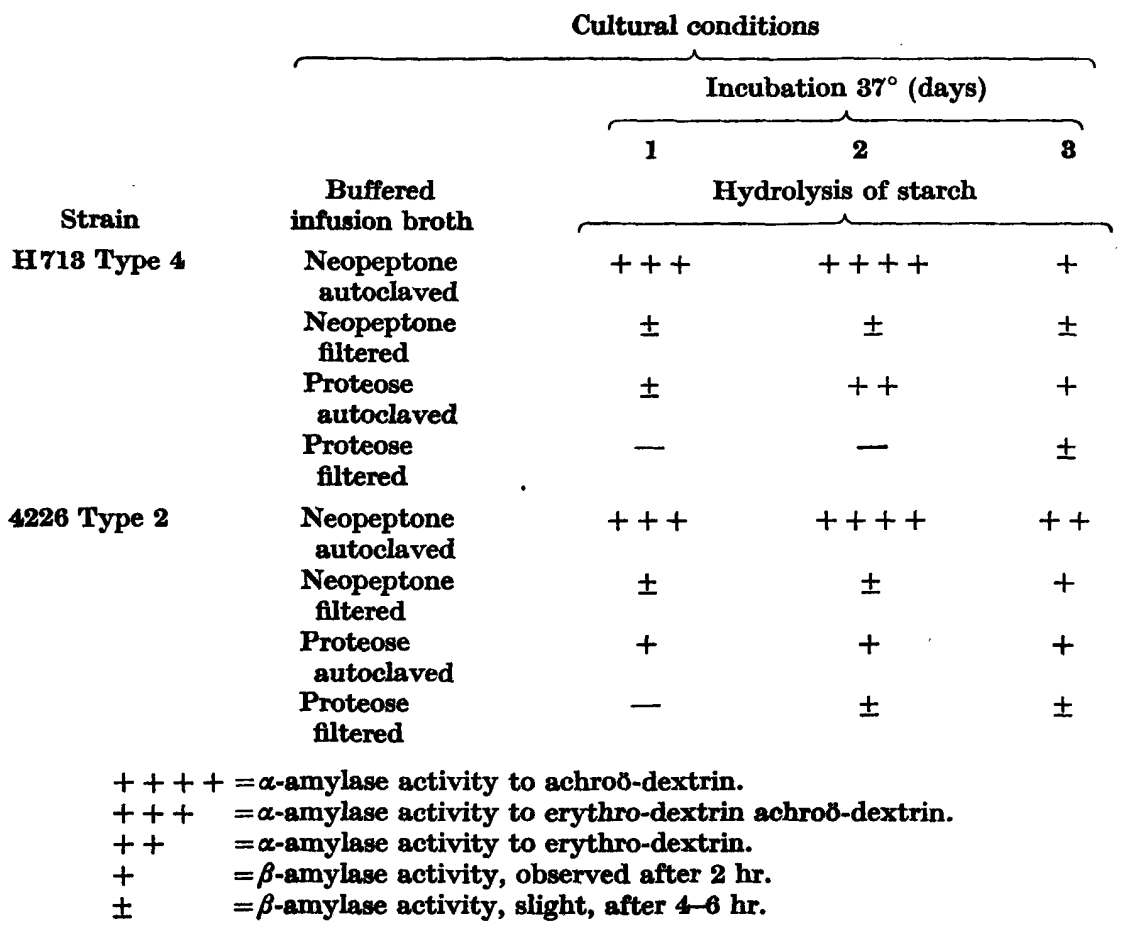

Table 9. The effect of incubation at $23^{\circ}$ on amylase production

Hydrolysis of $0.2 \%$ soluble starch by culture supernatants the flnal readings being made after overnight incubation at $37^{\circ}$.

\begin{tabular}{|c|c|c|c|c|c|c|c|}
\hline \multicolumn{3}{|c|}{ Cultural conditions } & \multicolumn{5}{|c|}{ Period of incubation (days) } \\
\hline & & & $\mathbf{1}$ & 2 & $\mathbf{3}$ & 5 & 7 \\
\hline \multirow{3}{*}{$\begin{array}{l}\text { Strain } \\
\mathbf{H r 1 8}\end{array}$} & \multirow{3}{*}{$\begin{array}{c}\text { Broth } \\
\text { Neopeptone } \\
\text { autoclaved } \\
\text { broth } \\
\text { pH } 7 \cdot 4-7 \cdot 6\end{array}$} & \multirow{2}{*}{$\begin{array}{c}\text { Temperature of } \\
\text { incubation } \\
\mathbf{8 7}^{\circ}\end{array}$} & \multicolumn{5}{|c|}{ Degree of hydrolysis of starch } \\
\hline & & & +++ & +++ & + & + & \pm \\
\hline & & $\mathbf{2 3}^{\circ}$ & - & - & + & + & + \\
\hline \multirow[t]{2}{*}{4226} & $\begin{array}{l}\text { Neopeptone } \\
\text { autoclaved } \\
\text { broth }\end{array}$ & $87^{\circ}$ & +++ & $++t+$ & + & + & \pm \\
\hline & pH 7.4-7.6 & $\mathbf{2 3}^{\circ}$ & - & \pm & \pm & ++ & + \\
\hline
\end{tabular}

Symbols as in Table 8.

The depression of $\alpha$-amylase activity was more striking in Neopeptone filtered broth and both proteose peptone broths. These results could not be 
explained on grounds of poorer growth at a lower temperature. Hyaluronidase production was influenced in marked degree by the cultural conditions which affected $\alpha$-amylase.

The effect of re-incubation at $37^{\circ}$ of cultures grown at $23^{\circ}$. After 3 days at $23^{\circ}$ cultures were re-incubated at $37^{\circ}$ with the cells still present, and amylase production increased; but when the broths were filtered before re-incubation at $37^{\circ}$ no change was found. If the broth cultures were not sterilized by one filtration, when scanty growth appeared after 2 or 3 days, amylase production was slightly increased suggesting that viable organisms must be present to initiate enzyme production at $37^{\circ}$. Filtrates known to be unsterile were divided into $10 \mathrm{ml}$. volumes, and $1 \mathrm{~mm}$. loopfuls of various growth factors, enzyme inhibitors and possible activators added before re-incubation at $37^{\circ}$. The substances added can be divided into three groups: (1) groroth factors, added on the assumption that a heat labile inhibitory factor was destroyed by autoclaving; these were aneurin, nicotinamide, nicotinic acid, riboflavin, yeast nucleic acid, liver extract ('Anahaemin', British Drug Houses Ltd.), and casein hydrolysate ('Casydrol', Glaxo Laboratories); (2) enxymes already known to activate streptococcal pro-

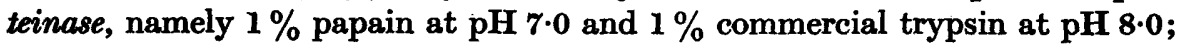
(3) substances or environmental alterations included on general grounds, namely starch powder and solution, potassium hyaluronate, and an atmosphere of $10 \%$

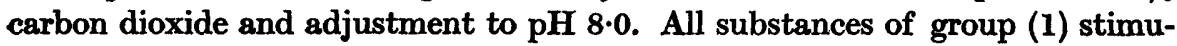
lated heavy growth overnight but without corresponding enhancement of enzyme production. 'Casydrol' suppressed amylolytic activity both in active control cultures and in hydrolysis tests. Papain, trypsin, $\mathrm{CO}_{2}$ in gas phase and a $\mathrm{pH}$ value of $\mathbf{8 . 0}$ appeared to cause a slight increase in activity whether or not growth was increased, but the increase was within the limits of experimental error. These results suggest the possible existence of an inactive precursor of streptococcal amylase analogous to the precursor of streptococcal proteinase (Elliott \& Dole, 1947); this possibility has not yet been fully investigated.

The effect of mouse passage. With the primary object of recovering $M$ antigen in order to determine the specific types of amylase-producing strains of the T antigen groups 4, 24, 26, 28, 29 and 46, four strains were chosen for mouse passage. Two proteinase-positive polysaccharidase-variable strains, and two polysaccharidase-positive proteinase-variable strains (all agglutinated by Type 4 serum) were selected at random from the collection of old cultures. The strains were mouse avirulent and $M$ antigen could not be demonstrated by precipitin tests. The effect of serial mouse passage on enzyme production is shown in Table 10. Capsules could not be demonstrated in any strain immediately after the last passage.

\section{The influence of proteinase on polysaccharidase activity in the same cultures}

Factors affecting proteinase production also affected polysaccharidase production, therefore the effect of proteinase alone has been difficult to assess. In the absence of proteinase, proteose peptone did not promote $\alpha$-amylase production, but on the other hand proteinase was activated even in the presence 
of Neopeptone when some strains were grown in soft agar. Nevertheless, there was a quantitative decrease in $\alpha$-amylase production in cultures containing both proteose peptone and active proteinase: Unfortunately, the proteinase inhibitor monoiodoacetic acid had an uncertain effect on amylase activity, and a convincing controlled experiment was not made. Evidence of inhibition by active proteinase in growing cultures is circumstantial; all that can be reported at present is that Type 4 strains, which were strongly proteinase-positive

\section{Table 10. The suppression of polysaccharidases and proteinase after mouse passage: recovery of type specific $M$ antigen}

Amylase $++++=\alpha$-amylase activity. $0 / \pm=$ slight $\beta$-amylase activity. Hyaluronidase $++t+=$ MCP titre $1 / 2000$. $0 / t=0-1 / 200$, using synovial fluid; 0 using umbilical hyaluronate. Proteinase $++++=$ coagulation of milk thiolacetate mixture within 15 min., in tube containing $1 / 4$ initial dilution of sample.

Enzyme production in 2-day cultures $\left(37^{\circ}\right)$ in favourable broth

\begin{tabular}{|c|c|c|c|c|c|}
\hline \multirow{2}{*}{\multicolumn{2}{|c|}{ Strain injected into mice }} & & & & \\
\hline & & \multirow{2}{*}{$\begin{array}{c}\text { Amylase } \\
++++ \\
0 / \pm\end{array}$} & \multirow{2}{*}{$\begin{array}{c}\text { Hyaluronidase } \\
++++ \\
\pm 10\end{array}$} & \multirow{2}{*}{$\begin{array}{c}\text { Proteinase } \\
-\end{array}$} & \multirow{2}{*}{$\begin{array}{c}M \text { antigen } \\
\frac{-}{4}\end{array}$} \\
\hline H713 & $\begin{array}{l}\text { Before passage } \\
\text { After passage }\end{array}$ & & & & \\
\hline K79 & $\begin{array}{l}\text { Before passage } \\
\text { After passage }\end{array}$ & $++t$ & $\begin{array}{c}+++ \\
-\end{array}$ & - & $\overline{4}$ \\
\hline $555 / \mathbf{E}$ & $\begin{array}{l}\text { Before passage } \\
\text { After passage }\end{array}$ & - & $\underline{0 /+}$ & $\begin{array}{c}+++ \\
-\end{array}$ & $\overline{4}$ \\
\hline M 185 & $\begin{array}{l}\text { Before passage } \\
\text { After passage }\end{array}$ & - & $\underline{0} /+$ & ++++ & $\overline{4}$ \\
\hline
\end{tabular}

without recourse to artificial activation, were always found to be $\alpha$-amylasenegative and hyaluronidase-negative or weak-variable. The circumstantial evidence is presented in Table 11.

\section{DISCUSSION}

Using methods different from those of Keogh \& Simmons (1940) it was found that though many strains attacked starch in broth cultures, extracellular amylolytic activity was confined, with two exceptions, to certain strains of one $\mathbf{T}$ antigen group. Moreover, the production of $\alpha$-amylase by Type 4 strains was associated, before mouse passage, with hyaluronidase production in the same culture. Until recently Type 4 strains having $M$ antigen and polysaccharidase activity at the same time had not been encountered, but fifteen Type 4 (M) strains isolated from an outbreak of streptococcal infection have now been found which possess polysaccharidase activity but show considerable strain variation both in hyaluronidase and amylase production. Familial epidemic capsulated strains (various types), which were hyaluronidasenegative, were previously found to be identical (Crowley, 1944). The present paper reports the results from the first opportunity of investigating the possibility that polysaccharidase activity increases with antigenic degradation of the strain. Though Type 4 strains have shown a greater range of polysaccharidase activity as compared with Types 24, 28 and 29 of the same group, this also depended on other biological components present in test cultures. 
Table 11. Correlation of polysaccharidases with proteinase activity in $T$ antigen group of closely related specific Types 4, 24, 26, 28, 29, 46

$\mathbf{A}=$ proteinase activated after agar passage. $0 /+=$ designations as in Table 10.

No. of strains showing activity

$\begin{array}{ccccc} & \text { Amylase } & \text { Hyaluronidase } & \text { Proteinase } \\ \mathbf{7} & ++++ & ++++ & - & \mathbf{A} \\ \mathbf{1} & + & ++ & - & \mathbf{A} \\ \mathbf{3} & - & ++ & - & \\ \mathbf{4} & - & \mathbf{0}++ & ++++ & \\ \mathbf{1} & - & - & +++ & \mathbf{+} \\ \mathbf{2} & + & - & \mathbf{0}+ & \mathbf{A} \\ \mathbf{1} & + & - & \mathbf{0} /+ & \mathbf{A} \\ \mathbf{3}^{*} & - & - & - & \mathbf{A} \\ \mathbf{2 2} & & & & \end{array}$

Strains specifically identified by $M$ antigen

\begin{tabular}{|c|c|c|c|c|c|}
\hline & & Amylase & Hyaluronidase & Proteinase & \\
\hline Type 4 & $\begin{array}{l}\mathbf{2} \\
\mathbf{2} \\
\mathbf{2}\end{array}$ & $\begin{array}{c}++++ \\
+1++++\end{array}$ & $\begin{array}{c}+++ \\
0 /+ \\
0 /++\end{array}$ & $\begin{array}{c}\overline{+}++ \\
-\end{array}$ & $\begin{array}{l}\text { Old strains } \\
\text { New strains; two representa- } \\
\text { tives showing minimum } \\
\text { and maximum }\end{array}$ \\
\hline Type 24 & 1 & + & E & o/t+ & \\
\hline $\begin{array}{l}\text { Type } 28 \\
\text { Type } 29\end{array}$ & $\begin{array}{l}1 \\
1\end{array}$ & \pm & - & $0 /+$ & \\
\hline
\end{tabular}

* All these strains persistently mucoid after years in artificial environment.

The effect of peptones on growth of streptococci has been studied by Dole (1946), on streptococcal proteinase by Elliott (1945) and on streptococcal nucleases by McCarty (1948). Elliott \& Dole (1947) also found that a dialysate broth was unfavourable for proteinase production. The findings with filtered broth as compared with heated broth suggest that a heat-labile factor delays autocatalytic processes. Growth at $\mathbf{2 3}^{\circ}$, which is favourable for cell antigens, was also unfavourable for carbohydrase production, and the metabolism may be similar to that in filtered broth. Considering the mouse merely as a culture medium, the results of passage show a more marked though similar effect. Failure of enzyme production in the presence of new growth initiated by yeast nucleic acid and other growth factors may also be interpreted in this way. The combined results support the hypothesis that environmental conditions favouring the synthesis of cell antigens are unfavourable for the production of these enzymes.

The similarity between mucolytic and amylolytic activity was noted by Robertson, Ropes \& Bauer (1940). McClean \& Hale (1941) found no correlation between the hyaluronidase activity of Clostridium septicum and $\mathrm{Cl}$. welchii and their ability to decrease the viscosity of starch pastes, but they noted that $\mathrm{NaCl}$ decreased both the amylolytic activity of $\mathrm{Cl}$. septicum and the activity of bacterial hyaluronidases. Many streptococcal filtrates decreased the viscosity of starch solutions but failed to show further amylolytic activity. It is now 
known that many Group A streptococci can alter the viscosity of three substances, hyaluronic acid, starch, and desoxyribonucleic acid as reported by McCarty (1948). In view of the opinion held by Baldwin (1948) that nucleases are pyrophosphatases it is interesting to note that Robertson, Ropes \& Bauer (1940) postulated that a phosphatase catalysed the first stage in viscosity change of gastric mucin. It seems possible that depolymerization of viscous substances by Group A streptococci may be a function of one enzyme of low specificity, comparable with the relative substrate specificity shown by some phosphatases. The close similarity of the methods of attack on two large molecules by the same culture filtrate also suggests that a further stage in the degradation of starch and hyaluronate may be catalysed by one relatively specific polysaccharidase. It became apparent in the course of this study that the polysaccharidases of Type 4 and Type 22 strains decomposed the substrate differently, each type having its own specific reaction-path, perhaps determined by the antigenic structure of the strain. The use of a second polysaccharide substrate as a screening test may reveal further strain differences, and other macromolecules might be used instead of starch for amylase-negative strains. Starch has advantages as a substrate for use in multiple tests since cheap and reasonably standardized preparations are readily available.

It may be mentioned here that the primary object of this paper was not to add yet another extracellular enzyme to the battery already displayed by Group A streptococci, but to find a reason for the association of the mucin clot-preventing enzymes with certain antigenic components. Any attempt to interpret the biological significance of streptococcal hyaluronidase without reference to all the cellular components may be as delusive as the interpretation of the significance of hyaluronic acid, which, as Meyer (1947) pointed out, is a large molecule not well understood. It also seems possible that the concept of absolute substrate specificity may have hypnotized some investigators of Group A streptococcal enzymes. Polysaccharidase activity in vitro, whether confined to strains with related antigens in the circumstances described here, or demonstrated elsewhere by unrelated strains in different test conditions, is on the whole exceptional. As the optimal conditions for in vitro production seem unlikely to pertain in vivo, it may be reasonable to regard such strains as deviating from the usual rule. The explanation for this may possibly be found in the specific growth requirements and adaptability of the strains. If further evidence of an inactive precursor is forthcoming, the in vivo mechanism of hyaluronidase production might be explained. The biological significance of streptococcal hyaluronidase may have to be interpreted in relation to all the cellular components, and though the exceptional strains may yet prove the rule, it is still uncertain what that rule may be.

Part of this work was done at the Streptococcal Reference Laboratory, and I wish to thank Dr V. D. Allison for this facility. At Colindale, Mr W. R. Maxted gave me valuable suggestions and generous help with precipitin tests and mouse passage. I also wish to thank Miss J. Woodhouse and Miss D. Keys at the Royal Free Hospital, for their painstaking preparation of the various infusion broths. 


\section{REFERENCES}

ANDREwEs, F. W. (1930). Note on the fermentation of starch by certain haemolytic streptococci. J. Path. Bact. 33, 145.

Bardwrin, E. (1948). Dymamic Aspects of Biochemistry, 2nd ed. Cambridge University Press.

ButT, E. M., Bonynae, C. W. \& Joyce, R. L. (1986). The demonstration of capsules about haemolytic streptococci with india ink or Azo blue. J. infect. Dis. 58, 5 .

Crowley, N. (1944). Hyaluronidase production by haemolytic streptococci of human origin. J. Path. Bact. 56, 27.

Dowe, V. P. (1946). A dialysate medium for the culture of Group A streptococci. Proc. Soc. exp. Biol., N.Y., 63, 122.

EuwotT, S. D. (1943). Type relationships among Group A streptococci. Brit. J. exp. Path. 24, 150.

Eurrotr, S. D. (1945). A proteolytic enzyme produced by Group A streptococci with special reference to its effect on the type specific $M$ antigen. J.exp. Med. 81, 578.

Eumotr, S. D. \& Dole, V. P. (1947). An inactive precursor of streptococcal proteinase. J. exp. Med. 85, 305.

GriffTth, F. (1934). The serological classification of streptococcus pyogenes. J. Hyg., Camb., 34, 542.

KeOGh, E. V. \& Simmons; R. T. (1940). Cultural methods as an aid in type differentiation of Group A haemolytic streptococci. J. Path. Bact. 50, 137.

Lanceftend, R. C. (1940). Type specific antigens, $M$ and $T$, or matt and glossy variants of Group A streptococci. J. exp. Med. 71, 539.

LanCEFteld, R. C. (1940-1). Specific relationship of cell composition to biological activity of haemolytic streptococci. Harvey Lect. 36, 251.

LANCEFTELD, R. C. (1943). Studies of the antigenic composition of Group A streptococci. J. exp. Med. 78, 465.

LANCEmend, R. C. \& Dole, V. P. (1946). The properties of T antigens extracted from Group A streptococci. J. exp. Med. 84, 449.

Maxtred, W. R. (1948). Preparation of streptococcal extracts for Lancefield grouping. Lancet, ii, 255.

MCCARTY, M. (1948). The occurrence of nucleases in culture filtrates of Group $A$ streptococci. J. exp. Med. 88, 181.

McClean, D. (1942). The in vivo decapsulation of streptococci by hyaluronidase. J. Path. Bact. 54, 284.

McCuean, D. \& Hate, C. W. (1941). Studies on diffusing factors. Biochem. J. 35, 159.

MEYER, K. (1947). The biological significance of hyaluronic acid and hyaluronidase. Physiol. Rev. 27, 8.

Mries, A. A. \& Misra, S. S. (1938). The estimation of the bactericidal powers of the blood. J. Hyg., Camb., 38, 782.

Philurs, R. A., Van Slyke, D. D., Dole, V. P., Emerson, K. jr., Hamilon, P. B. \& ARChibald, R. M. (1945). Copper sulphate method for measuring specific gravities of whole blood and plasma. Indian med. Gaz. 80, 275.

Pike, R. M. (1948). Studies on streptococcal hyaluronic acid and hyaluronidase. J. infect. Dis. 83, 1.

Robertson, W. van B., Ropes, M. W. \& Bauer, W. (1940). Mucinase: A bacterial enzyme which hydrolyses synovial fluid mucin and other mucins. J. biol. Chem. 133, 261:

Rogers, H. J. (1944). A simplified culture medium for the production and purification of hyaluronidase. J. Path. Bact. 66, 284. 
Rogrrs, H. J. (1948). The complexity of bacterial hyaluronidases. Biochem. J. 42, 663.

Shrmman, J. (1937). The streptococci. Bact. Rev. 1, 3.

Swirt, H., Wrison, A. \& Lancefiend, R. C. (1943). The typing of Group A streptococci by $M$ precipitin reactions in capillary pipettes. J. exp. Med. 78, 127 .

ToDd, E. W. \& HewIT, L. (1932). A new culture medium for the production of antigenic haemolysin. J. Path. Bact. 35, 973.

(Received 11 July 1949) 